\title{
PEMANFAATAN GOOGLE FORMS PADA ORGANISASI PENELITI SEBAGAI UPAYA KONTRIBUSI MENINGKATKAN MINAT RISET DI KOTA MEDAN
}

\author{
Fifin Sonata ${ }^{1}$, Dede Prabowo Wiguna ${ }^{2 *}$, Juniar Hutagalung ${ }^{3}$ \\ ${ }^{1,3}$ Prodi Manajemen Informatika, STMIK Triguna Dharma \\ ${ }^{2}$ Prodi Sistem Informasi, Sekolah Tinggi Ilmu Komputer Medan \\ email: dede.prabowo@alumni.ui.ac.id
}

\begin{abstract}
The low number and results of researchers forms the basis of the need for programs to boost research interest for the community. In addition, the imbalance of research results in the field of research in Indonesia compared to other countries must have efforts and solutions to overcome these problems. One of the efforts made by utilizing the Google Forms application in research organizations in creating Science Event programs (LKTI). LKTI is an activity of scientific writing competition which is done by forming a committee and selecting a jury according to the contested field. The method used is by selecting the manuscript, percentage and judging. The manuscript selection process is carried out by checking the registered participant manuscripts using plagiarism tests. An appropriate script will be assessed to determine the finalists based on the highest score. Then, the finalists make a presentation before the jury using power point media. Plagiarism and percentage test scores are then accumulated by the jury to determine the winner. The results of the activity decided three winners as champions 1,2 and 3 based on the results of the jury's assessment of the finalists. Participants who won were given awards in the form of trophies, certificates, and coaching money. The activity ran smoothly with the hope that in the future the interest of the community to research will increase and the research work will be better.
\end{abstract}

\section{Keyword: google forms; LKTI; researchers organization}

\begin{abstract}
Abstrak: Rendahnya jumlah peneliti dan hasil riset menjadi dasar perlunya program untuk menggenjot minat riset bagi masyarakat. Selain itu, timpangnya hasil penelitian dalam bidang riset Indonesia dibandingkan dengan negara lain harus ada upaya dan solusi mengatasi permasalahan tersebut. Salah satu upaya yang dilakukan dengan pemanfaatan aplikasi Google Forms pada organisasi peneliti dalam membuat program Science Event (LKTI). LKTI merupakan kegiatan lomba karya tulis ilmiah yang dilakukan dengan membentuk kepanitian dan memilih juri sesuai bidang yang dilombakan. Metode yang digunakan yaitu dengan menseleksi naskah, presentase dan penjurian. Proses seleksi naskah dilakukan dengan mengecek naskah preserta yang mendaftar dengan menggunakan tes plagiasi. Naskah yang layak akan dinilai untuk menentukan finalis berdasarkan nilai tertinggi. Kemudian, finalis melakukan presentase dihadapan dewan juri menggunakan media power point. Nilai tes plagiasi dan presentase kemudian diakumulatif oleh dewan juri untuk menentukan pemenang. Hasil kegiatan memutuskan tiga pemenang sebagai juara 1,2 dan 3 berdasarkan hasil penilaian dewan juri kepada para finalis. Peserta yang juara diberikan penghargaan berupa trophy, sertifikat, dan uang pembinaan. Kegiatan berjalan dengan lancar dengan harapan kedepan minat masyarakat untuk meneliti semakin meningkat dan karya penelitiannya semakin baik.
\end{abstract}

Kata kunci: google formulir; LKTI; organisasi peneliti 
Available online at https://jurnal.stmikroyal.ac.id/index.php/jurdimas

\section{PENDAHULUAN}

Rendahnya jumlah peneliti dan hasil riset mengakibatkan posisi Indonesia masih tertinggal dan belum sejajar dengan negara maju. Padahal, salah satu indikator suatu negara dapat mengalami kemajuan yaitu harus ditopang dari riset dan peneliti. Informasi yang ditayangkan harian kompas menerangkan bahwa LIPI pada tahun 2015 pernah membandingkan jumlah peneliti Indonesia dengan India, Brasil, Rusia, Tiongkok, dan Korea. Saat ini, jumlah peneliti Indonesia hanya 90 peneliti per satu juta penduduk. Sementara itu, jumlah peneliti Brasil mencapai 700 orang per 1 juta penduduk. Rusia 3000 peneliti per 1 juta penduduk, India 160 peneliti per 1 juta penduduk, Korea 5.900 peneliti per 1 juta penduduk, dan Tiongkok 1020 peneliti per 1 juta penduduk. Kalau penduduk China 2 miliar orang, mereka memiliki 2 juta peneliti.

Secara umum, jumlah dan hasil riset merupakan muara. Dalam prosesnya tentu banyak faktor yang mempengaruhinya. Seperti yang diutarakan (Lertputtarak, 2008) dalam disertasinya menyatakan bahwa yang memengaruhi seseorang dalam melakukan kegiatan penelitian adalah personal career development factors yang secara langsung memengaruhi motivasi diri dan self-confidence yang berasal dari pengalaman dan keterampilan untuk melakukan kegiatan penelitian.

Di sisi lain, dalam konteks kegiatan penelitian yang dilakukan pada dunia kampus, (Bolliger \& Wasilik, 2009) mengatakan bahwa insentif keuangan untuk melakukan penelitian, budaya penelitian yang kondusif, dan dukungan penelitian yang diberikan oleh universitas mempunyai pengaruh yang signifikan terhadap produktivitas riset dan ketidakpuasan terhadap tersedianya sumber daya. Hasil penelitian (Muljo, 2012) juga menerangkan hampir sama bahwa didunia kampus rendahnya dosen dalam meneliti dipengaruhi oleh dana dan minat meneliti. Hasil penelitinya menyatakan adanya hubungan yang signifikan antara dana $\left(\mathrm{X}_{1}\right)$ dengan minat meneliti (Y).

Melihat timpangnya bidang riset Indonesia dibandingkan dengan negara lainnya dan juga permasalahan dalam dunia penelitian yang cenderung masih kurang produktif, maka harus ada usaha untuk menggenjot bidang riset. Salah satu usaha yang dapat dilakukan ialah mendirikan serta pemanfaatan organisasi peneliti. Sebagai asosiasi yang bergelut di bidang penelitian perlu membuat program yang dapat meningkatkan minat riset. Program yang baru saja dilaksanakan untuk meningkatkan minat riset yaitu Science Event Lomba Karya Tulis Ilmiah (LKTI) Tahun 2020 Asosiasi Peneliti Sumatera Utara (APSU).

Oleh sebab itu, diharapkan dengan pemanfaatan organisasi peneliti seperti ini dapat berkontribusi dalam meningkatkan minat riset masyararakat di Kota Medan secara khusus dan Indonesia pada umumnya.

Pada skala nasional, Indonesia memiliki lembaga resmi pemerintah seperti LIPI. Sementara, pada skala lokal APSU hadir memposisikan sebagai organisasi social atau lembaga swasta independen yang juga fokus membantu dalam usaha meningkatkan jumlah riset dan sumber daya peneliti di Sumatera Utara. (Unayah, 2011) mengatakan mengenai kontribusi 
Available online at https://jurnal.stmikroyal.ac.id/index.php/jurdimas

organisasi sosial bahwa kontribusi organisasi sosial dapat dipahami sebagai sumbangan atau dukungan yang diberikan oleh orsos dalam menanggulangi berbagai permasalahan sosial. Dalam kaitannya dengan penelitian ini kontribusi dapat dipahami sebagai wujud partisipasi masyarakat dalam pembangunan kesejahteraan social (Indarti \& Langenberg, 2004). Wujud partisipasi masyarakat yang dimaksud adalah pemikiran, kemampuan, tenaga, keahlian, material dan lain-lain. Diharapkan dengan adanya dukungan atau sumbangan orsos dapat mencegah dan menanggulangi permasalahan sosial yang ada dilingkungannya (Rumah, Dan, \& Administrasi, 2007).

\section{METODE}

Penelitian ini menggunakan metode action research (penelitian tindakan). Data diolah melalui kegiatan yang dilakukan. Data yang dikumpulkan berupa data kuantitatif naskah peserta yang mendaftar dan data dokumentasi. Program ini sudah direncanakan sejak tahun 2019. Program ini diinisiasi melalui bidang Publikasi Ilmiah Asosiasi Peneliti Sumatera Utara. Rencana awal di bulan oktober buka pendaftaran dan pengumpulan naskah akhir Desember 2019. Proses pendaftaran dilakukan dengan aplikasi google forms. Kemudian, presentasi finalis dan penentuan pemenang lomba awal januari tahun 2020. Namun, rendahnya minat yang mendaftar sehingga panitia memperpanjang hingga penjurian awal februari tahun 2020 .

Untuk bidang lomba fokus pada bidang kemaritiman, science dan komputer, pendidikan, sosial budaya, ekonomi dan pertanian. Bidang yang diperlombakan disesuaikan dengan topik yang digagas yaitu Inovasi Ilmu Pengetahuan di Era Revolusi Industri 4.0 Untuk Mewujudkan Sumut Bermartabat. Adapun syarat karya tulis yang diusulkan setiap kategori (Dosen/Pendidik, Mahasiswa dan Pelajar) harus orisinal dan belum pernah dipublikasikan serta sesuai dengan sistematika lomba.

\section{PEMBAHASAN}

Dari hasil pengumpulan naskah yang sudah dilakukan oleh panitia selama hampir tiga bulan, terkumpul sebanyak lebih kurang 25 naskah. Pendaftaran lomba dilakukan menggunakan aplikasi google forms. Selanjutnya, panitia melakukan pensortiran naskah yang layak untuk dilanjutkan dalam science event LKTI Tahun 2020. Berikut hasil pengumpulan naskah pendaftaran peserta melalui halaman google forms.

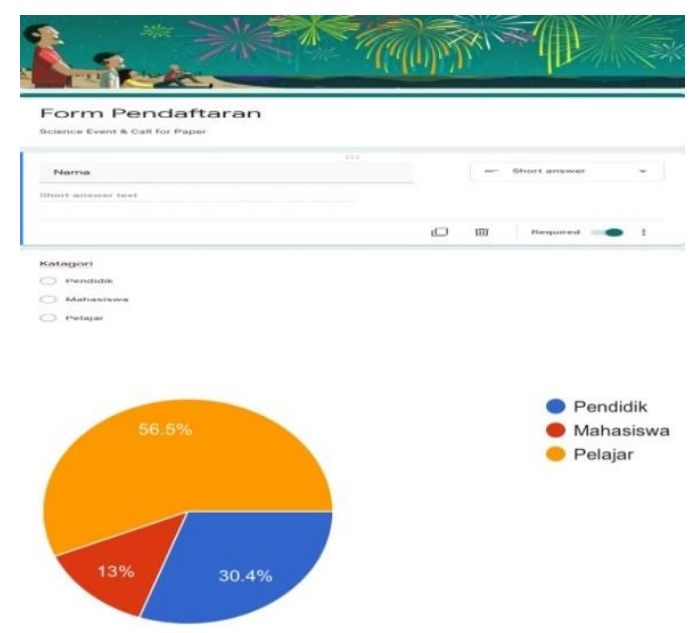

Gambar 1. Naskah yang Masuk Tiap Kategori

Sumber: Google Forms Pendaftaran Science Event LKTI APSU Tahun 2020 
Available online at https://jurnal.stmikroyal.ac.id/index.php/jurdimas

Pada data gambar 1, terlihat bahwa kategori pelajar mendominasi peserta yang mendaftar yaitu sebesar 56,5 persen. Sementara, kategori pendidik yang mendaftar sebesar 40,4 persen dan kategori mahasiswa yang mendaftar sebesar 13 persen. Data ini masih berupa data mentah yang selanjutnya akan di cek keorisinalan naskahnya menggunakan aplikasi tes plagiat. Adapun rangkaian acara yang dilakukan sebelum diputuskan pemenang sebagai juara 1, 2, dan 3 dijelaskan sebagai berikut.

\section{Pembukaan Science Event LKTI APSU Tahun 2020}

Acara dilakukan bertempat di Roemah 28 Kota Medan. Pembukaan acara di bawakan oleh MC dan sambutan dari ketua panitia. Acara melibatkan dewan juri, peserta dan guru pembimbing yang hadir dalam kegiatan. Partisipasi untuk kategori pelajar cukup antusias saat kegiatan berlangsung. Hal ini tampak dari kelompok dan tim yang siap presentasi yang sudah dibagi berdasarkan tugasnya masing-masing. Peserta yang berpartisipasi bukan hanya dari Kota Medan saja, tetapi hadir juga peserta dari luar Kota Medan dengan penuh semangat.

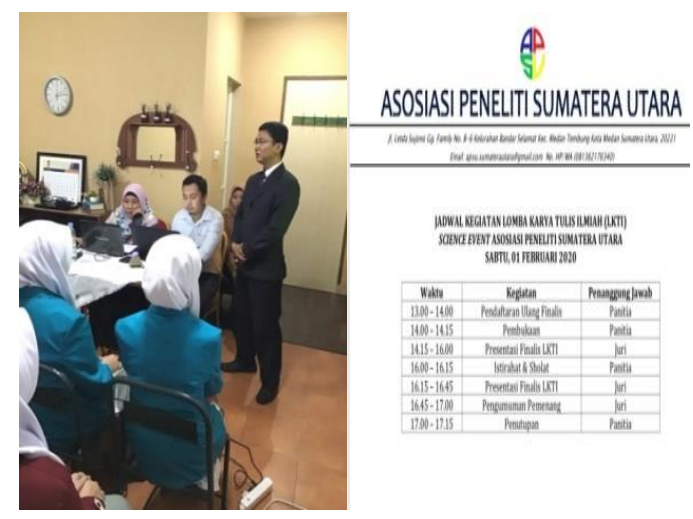

Gambar 2. Pembukaan Science Event LKTI APSU Tahun 2020

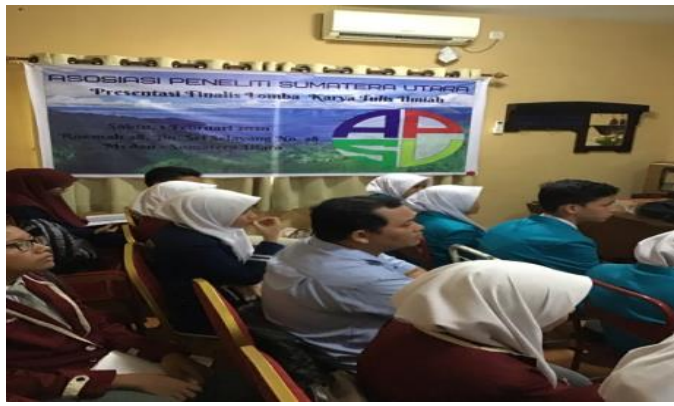

Gambar 3. Pembukaan Science Event LKTI APSU Tahun 2020

\section{Tahap Penilaian dan Penjurian Naskah}

Pada tahap ini, masing-masing peserta finalis tiap kategori mempresentasikan naskahnya dihadapan dewan juri. Penilaian naskah dilakukan berdasarkan sistematika penulisan dan presentase yang memiliki bobot nilai. Selanjutnya, hasil diakumulatif dari nilai dewan juri 1 dan 2. Adapun kriteria penilai mengacu pada ketentuan; (1) substansi (tujuan, metode, hasil) dan kesesuaian dengan sistematika dengan bobot maksimal 30, (2) inovasi dan Tingkat Kesiapan Teknologi (TKT) dengan bobot maksimal 20, (3) presentasi finalis (Penalaran, teknik penyajian, alat bantu/media yang digunakan, penggunaan bahasa, ketepatan waktu, penampilan). Berikut ini adalah tahapan penilaian naskah dan presentase.

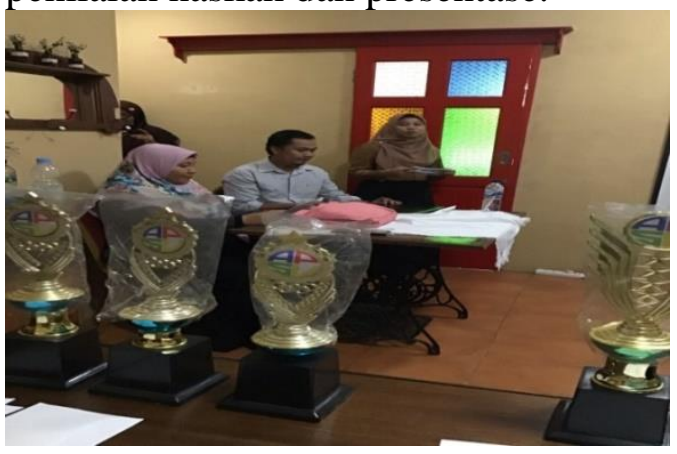

Gambar 3. Dewan Juri dan Presentase Naskah 
Available online at https://jurnal.stmikroyal.ac.id/index.php/jurdimas

\section{Tahap Pengumuman Pemenang}

Setelah semua peserta sudah mempresentasekan hasil riset dan karya tulisnya, saatnya dewan juri menentukan pemenang lomba. Tentu menentukan pemenang bagi dewan juri tidak mudah. Sebab, naskah yang dinilai hampir semuanya bagus. Namun, karena lomba harus diputuskan pemenangnya maka dewan juri meranking pemenang lomba Juara 1,2 dan 3. Peserta tiap kategori mendapatkan hadiah trophy, sertifikat dan uang pembinaan.

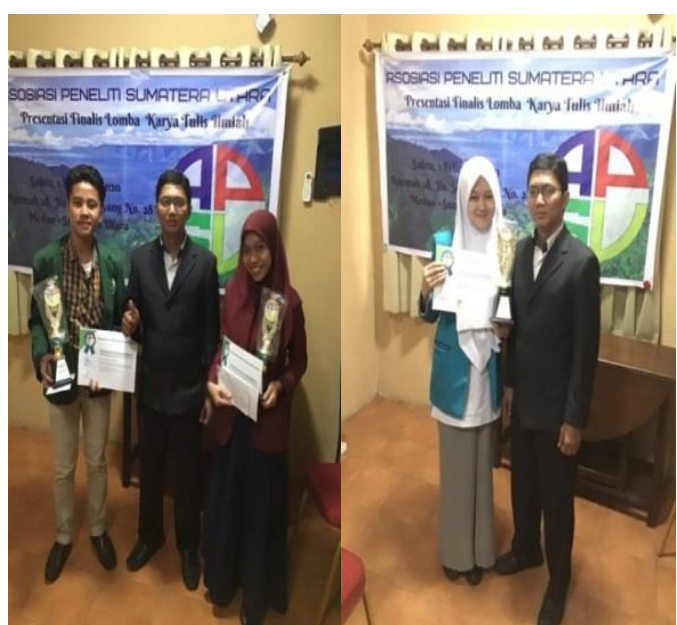

Gambar 4. Pemenang Lomba Science Event LKTI APSU Tahun 2020

\section{Penutupan}

Setelah acara selesai, peserta, dewan juri dan panitia berkesempatan foto bersama sebagai dokumentasi kegiatan. Panitia berterima kasih kepada dewan juri yang sudah meluangkan waktu dan berkenan hadir untuk menjuri dalam kegiatan ini. Hasil keputusan lomba dan pemenang dari dewan sifat mutlak dan tidak dapat diganggu gugat. Berikut ini foto bersama dewan juri dan panitia lomba.

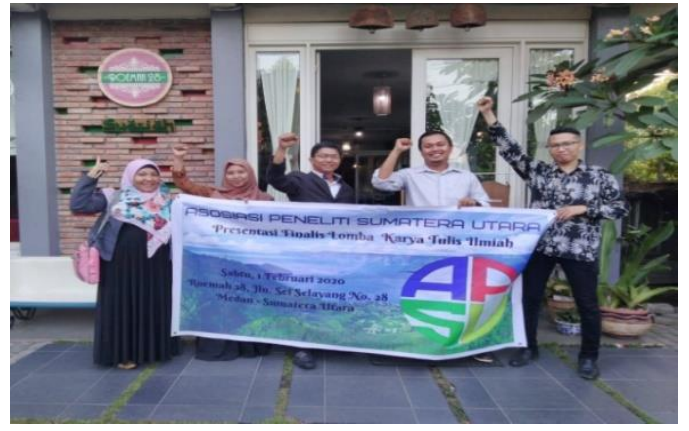

Gambar 5. Dewan Juri dan Panitia Science Event LKTI APSU Tahun 2020

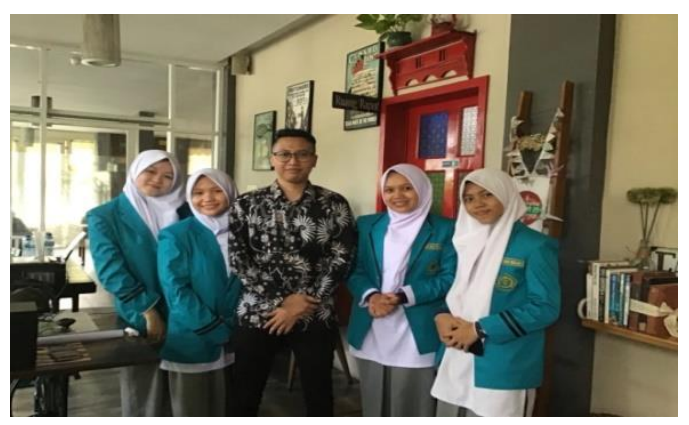

Gambar 6. Ketua APSU dan Peserta Science Event LKTI APSU Tahun 2020

\section{SIMPULAN}

Dari rangkaian kegiatan pengabdian kepada masyarakat yang sudah dilakukan dapat disimpulkan bahwa kegiatan ini sebagai upaya untuk menstimulus masyarakat dalam meneliti atau riset sehingga dapat meningkatkan minat dan jumlah peneliti di Kota Medan secara khusus. Hasil kegiatan ini memutuskan juara 1,2, dan 3 yang berasal dari sekolah dan Perguruan Tinggi di Kota Medan, Kota Binjai dan Kota Tebing Tinggi dengan judul penelitian yang cukup bagus dari masing-masing kategori. Pengabdian masyarakat ini berjalan dengan lancar, meskipun setiap kegiatan tentu saja terdapat hambatan. 
Available online at https://jurnal.stmikroyal.ac.id/index.php/jurdimas

\section{UCAPAN TERIMA KASIH}

Ucapan terima kasih kepada Asosiasi Peneliti Sumatera Utara, ketua panitia kegiatan saudara M. Iman Hidayat, M.Pd, kepada Dewan Juri sekalian.

\section{DAFTAR PUSTAKA}

Bolliger, D. U., \& Wasilik, O. (2009). Factors influencing faculty satisfaction with online teaching and learning in higher education. Distance Education, 30(1), 103116.

https://doi.org/10.1080/015879109 02845949

Indarti, N., \& Langenberg, M. (2004). Factors affecting business success among SMEs: empirical evidences from Indonesia. Second Bi-Annual European Summer ..., (August), 115. Retrieved from http://www.utwente.nl/mb/nikos/ar chief/esu2004/papers/indartilangen berg.pdf

Lertputtarak, S. (2008). An Investigation of Factors Related to Research Productivity in a Public University in Thailand: A Case Study, 317.

Muljo, H. H. (2012). Pengaruh Dana dan Waktu Dosen terhadap Minat Meneliti: Studi Kasus Universitas Bina Nusantara. Binus Business Review, 3(1), 173. https://doi.org/10.21512/bbr.v3i1.1 293

Rumah, A., Dan, T. A., \& Administrasi, P. (2007). Peningkatan Kualitas Organisasi Melalui Anggaran Dasar, Hal. 424-429.

Unayah, N. (2011). Kontribusi Organisasi Sosial Dalam Pembangunan Kesejahteraan Sosial. Penelitian Dan Pengembangan Kesejahteraan Sosial, 85-100. 